\title{
Outcome Measures Non-Performing Loans on BPR Sejahtera Klaten of Central Java
}

\begin{abstract}
Riskha Amaliya Lubis $^{1}$ and Maryanto ${ }^{2}$
Abstract. If there are non-performing loans carried out by the debtor, then the bank can take action to overcome the problem loans. In the course of installments in the event of a month (double / substandard), the Bank's officer will make a collection to return smoothly, but in reality the debtor is difficult, to meet with the Bank. Factors that cause the BPR Sejahtera Klaten. Selecting non-litigation pathways in resolving problem loans. Because it saves time, costs, outputs that can be Achieved, approaches with good faith, the ability to pay customers are considered. In taking out credit guarantees, the bad creditors can not enforce coercion Because It is an illegal act. Therefore the problem of bad credit requires a wise solution where the parties do not feel disadvantaged.
\end{abstract}

Keywords: Non-Performing Loans; Wise Settlement.

\section{Introduction}

Financial institutions, such as banks and non-banks have an important role for economic development in Indonesia. That role is as an infrastructure to collect funds and distributing public funds. Based on Act No. 7 of 1992 on banking as amended by Act No. 10 of 1998, the Bank is an entity that collects funds from the public in the form of savings and channeled back to the community in the form of credit in order to improve the standard of living of the people.

One of the products provided by the bank in helping to smooth the business customer (debtor) is the granting of loans, of which this is one of the functions of banks are very supportive of economic growth. Banks have an important position in providing services in the field of credit. Bank credit helped the availability of funds to finance national production, storage of material, sales credit financing, transportation of goods, trade. ${ }^{3}$ Credit became a source of revenue and profit of the largest bank in addition to credit is a type of activities of the fund are often the main cause banks face a big problem. It is also pointed out by an expert in the field of credit, namely: "Credit in the economic sense interpreted as a delay in payment of achievement that is given now in the form of money, goods or services". 4

\footnotetext{
1 Student of Master of Law, Universitas Islam Sultan Agung Semarang and Advocates Email riskha.yulianto@gmail.com

${ }^{2}$ Lecture of Faculty of Law UNISSULA Semarang,

${ }^{3}$ Siswanto Sutojo Analisis Bank Perkreditan Rakyat: Konsep dan Teknik PT. Reader Binaman Pressindo Jakarta 1995 p. 2-3.

${ }^{4}$ Mohammad Djumhana 2006 Hukum Perbankan di Indonesia PT. Citra Aditya Bakti Bandung p. 217.
} 
Banks provide credit facilities with the aim to enable customers easily borrow money to loan credit programs that have terms and conditions. In determining the eligible prospective borrowers, banks apply the precautionary principle, with the idea that having a bearing on acceptance of credit worthiness is five $\mathrm{C}$ namely; Character, Capacity, Capital, Condition, Collateral.

In general, the bank has provided certain credit form accompanied by requirements that must be fulfilled by the loan applicant. Although the loan applicant has met the requirements in the proposed, not necessarily of the banks provide credit facilities.

If the debtor deliberately not repay their debts and did not keep the deadline of repayment guarantee and can be used to replace debt. Therefore, a credit guarantee must exist on each lending by banks. In practice often debtors fail to execute its business. This makes the debtor is not able to repay loans in a timely manner obtain it with. As already in the know that credit is a loan agreement to borrow money, the debtor who can not pay off debts after term ended is in default. ${ }^{5}$

Based on the above description of the background writer was interested in reviewing the loan resolution that occurs in PT. Rural Banks (BPR) Klaten Prosperous and lifted it in the title of research as follows: NPL Resolution Efforts At BPR Sejahtera Klaten district of Central Java

To facilitate the understanding in the discussion that will be examined and to clarify the object has been determined, as for the formulation of the problem in this research are as follows: What causes bad loans in BPR Sejahtera Klaten, both the debtor and creditor ?; What are the procedures loan resolution efforts in BPR Sejahtera Klaten?; How legal consequences for borrowers who are in default in BPR Sejahtera Klaten?

\section{Results and Discussion}

\subsection{Overview of the Credit Banking}

Base relationship between the bank and its clients is a contractual relationship, so a customer to establish contractual agreement with the bank, it is an agreement on the basis of agreement or contract. Medium according to the meaning of the word "credit" comes from the Roman "credere" means to believe (Dutch: vetrouvmen, trust or confidence). Legally credit terms set out in Article 1 point 11 of Act no. 10 of 1998 concerning amendments to the Act no. 7 of 1992 on banking. According to Article 1 number 11 of Act No. 10 of 1998: "Credit is the provision of cash or the equivalent, based on the approval or the borrowing and lending between banks and other parties who require the borrower to repay the debt after a certain period with giving flowers". ${ }^{6}$ :

- Trust

\footnotetext{
${ }^{5}$ Gatot Supramono 1995 Bank Perkreditan Sebuah Tinjauan Yuridis Djambatan Jakarta p. 92.

${ }^{6}$ Mohammed Djumhana 1993 Hukum Perbankan di Indonesia PT. Citra Aditya Bakti Bandung p.219.
} 
The belief is the belief of the lender that his achievements were given in the form of money, goods or services, it would be really receipt back within a certain period in the future.

The grace period is a period that will separate administration with contra achievement that will be received in the future. In this element, embodied understanding of the value of the additional paid money, the money there are now more valuable than the money that will be received in the future.

- Degree of risk

Degree of risk ie the level of risk to be faced as a result of long periods of separation between the provision of the counter accomplishment achievement that will be received later. The longer the credit is given higher the level of risk, because the human ability to break through the future, it is still limited to non contingencies always there is an element that can not be taken into account. This is what causes the onset of an element of risk. With the element of risk here there arises a credit guarantee.

- Achievement

Achievement is not only the object of credit granted in the form of money, but also can take the form of goods or services. However, due to modern economic life is now based on money, the credit transactions related to money that is often encountered in the banking practice. The goals to be achieved from a lending bank are:

- For profit for the survival of the Bank

- Helping business customers who require funds

- Assist the government in tax revenue, employment opportunities, improving goods and services circulating in the community, saving and increasing the circulation of goods and services in the community and conserve and increase foreign exchange through increased exports. ${ }^{7}$

Settlement through this route was made through renewed talks between creditors and debtors to mitigate the terms of the credit agreement. So in the rescue phase is not using the line of credit because debtors are still cooperative litigation and the prospects of its business is still feasible. ${ }^{8}$ Handling of troubled bank credit under the provisions of Bank Indonesia Circular Letter No. 23/12 / BPP dated February 28, 1991 in an attempt to overcome the problem loans, the Bank can do some rescue measures as follows:

- Rescheduling

Rescheduling represents the first effort of the Bank for rescue loans to debtors. How this is done if it turns out the debtors (based on research results and calculations performed Bank account officer) was not able to meet the obligations in terms of repayment of principal and interest installment loan.

\footnotetext{
${ }^{7}$ Kamsir 1997 Bank dan Institusi Finansial PT. Raja Grafindo Jakarta p 96

${ }^{8}$ Sutarno 2003 Aspect legal of credit with the Bank Alfabeta Jakarta
} 
- Reconditioning

Reconditioning an attempt by the Bank to the rescue loans given by changing some or all of conditions (requirements) which was originally agreed with the debtor and the bank which then poured in the credit agreement. "Changes in credit conditions made with regard to the problems faced by the debtor in the execution of projects or business."

- Recstructuring

Recstructuring namely credit rescue effort that must be carried out by changing the composition of the Bank's financing of the underlying loans, according to Lukman Dendawijaya. Then, because of the difficulties experienced by customers in implementing their projects or business, the customer is not able to pay the loan principal and interest installment loans,

\subsection{Implementation of the BPR Sejahtera in Klaten}

Lending activities is the process of asset formation Bank. Credit is a risk asset for the bank because the bank assets controlled by outside parties, namely the debtor. Implementation bank credit has several provisions or requirements that must be implemented since the implementation of the petition filed by the keel of a customer up loans granted by the Bank. Credit procedures that must be handled by the Bank, namely, the stages of the loan application, investigation, and analysis, decision, approval, disbursement, supervision and loan repayment.

\subsection{Analysis of Non Performing Loans Company in BPR Sejahtera Klaten}

If there is problem loans made by the debtor, then the bank can perform an action to resolve the problem loans. In the case of installment passes through the moon (colap 2 /substandard), the Bank will perform the billing clerk to return smoothly, but in fact the debtor difficult to find by the Bank. In the case of late 3 months then it is in the category (colap 3 / Special Mention) if the status of the customer in this phase will be issued a letter of warning 1-3 and if there is no change then it can happen nonperforming loans, the Bank can provide a solution in case of credit problems through non-litigation.

\subsection{NPL Resolution Efforts of BPR Sejahtera Klaten Using Non-Litigation}

Measures troubled debt settlement can be reached with effort:

- "Rescheduling, which change only concerns credit terms and payment schedule or the time period including a grace period, both of which include changes in the amount or absence of installments. Rescheduling specifically aims to:

- Debtors can arrange direct funding "cash flow" is more uncertain.

- Ensuring a more appropriate payment.

- Allows borrowers to arrange payments to parties other than the Bank. 
- Eligibility back (reconditioning), the changes in some or all of the credit terms are not limited to changes in payment schedules, duration and or other requirements to the extent not concerned

- Realignment (restructuring), the change in credit terms concerning Raising funds by the Bank; Conversion of all or part of interest arrears into a new loan principal. Conversion of all or part of the credit to investment in the company. ${ }^{9}$

The presence of non-performing loans if the misfire which is a burden to the bank became one of the determinants of bank performance, and therefore their nonperforming loans when jammed requires the completion of a rapid, precise and accurate and require rescue and solving action immediately.

\section{Closing}

\subsection{Conclusion}

Credit problem can be caused by internal factors arise irregularities in the implementation of credit procedures, faith is less good than the owner, administrators, or employees of the bank, weak administrative systems and credit controls, while external factors causing bad credit is the failure of the debtor's business, on the business activities of the debtor and declining economic activity and high lending rates. Factors that cause BPR Sejahtera Klaten Prefer non-litigation lines, among others:

- Time, At the time of the settlement is one of the grounds for the settlement, through litigation if it takes a long time.

- Cost, The process of non-litigation settlement through does not cost that much to resolve problem loans.

- If the results achieved through non-litigation dispute resolution lines of credit can obtain maximum results.

- The reason for choosing the path of good faith non-litigation is still the willingness of the debtor to settle his credit.

\subsection{Suggestion}

In an effort to loan resolution, supposedly established a good cooperation between the customer, the bank and third parties who assist the settlement of the problem loans. Supervision and guidance that has been done by the bank should be increased, to provide the best solution

\section{Bibliography}

[1] Act No. 10 on the Amendment of Act No. 7 of 1992 on Banking.

[2] Gatot Supramono 1995 Bank Perkreditan Sebuah Tinjauan Yuridis Djambatan Jakarta

${ }^{9}$ Ibid. 
[3] Kamsir 1997 Bank dan Institusi Finansial PT. Raja Grafindo Jakarta

[4] Mohammad Djumhana 2006 Hukum Perbankan di Indonesia PT. Citra Aditya Bakti Bandung

[5] Mohammed Djumhana 1993 Hukum Perbankan di Indonesia PT. Citra Aditya Bakti Bandung

[6] Siswanto Sutojo 1995 Analisis Bank Perkreditan Rakyat: Konsep dan Teknik PT. Reader Binaman Pressindo Jakarta

[7] Sutarno 2003 Aspect legal of credit with the Bank Alfabeta Jakarta 